\title{
Pre-Collection of Domestic Waste in Slum Districts of Yaoundé in Cameroon: Socio-Economic and Sanitary Impact
}

\author{
${ }^{1}$ National Advanced School of Engineering Yaoundé, Cameroon \\ ${ }^{2}$ Francophony University Agency, Dakar, Senegal \\ ${ }^{3}$ University of Yaoundé I, Geography Departement, Cameroon \\ 4"Tam Tam Mobile”, Cameroon
}

Ngnikam Emmanuel $^{*}, 1$, Tanawa Emile ${ }^{2}$, Mougoue Benoît ${ }^{3}$ and Etoga Simon Pierre ${ }^{4}$

\begin{abstract}
In developing countries, the management of solid waste constitutes one of the main challenges of the present decade. A pre collecting pilot operation taking solid waste from individual households to municipal bins was implemented at Melen in Yaoundé.

The methods used for the preparation of this operation included meetings between project partners to agree on project objectives and implementation, the identification and interviewing of key actors, conducting a population census and an assessment of the waste generating activities in the targeted area, documenting research, meetings for information sharing and discussion with the inhabitants and the mapping of potential waste collecting itineraries in the targeted areas.

By the end of the first year of investigation, we identified the actors of waste management and the services they offered, identified the youth associations capable of waste collection process implementation, and assessed the population's ability to finance collection the cost of which varied between US\$1.25 and US\$5 per month. In addition, we noticed that $81 \%$ of the households were ready to pay for the pre collection of their waste. The project team endeavoured to create an environment that supported dialogue among various actors enabling follow-up and supervision of the process on the field. The assessment of the first 5 years of the waste program has proven the commitment of the inhabitants to participate in this type of operation through the direct payment for the service: $40 \%$ of the targeted households continued to pay for the pre collection service. The total contribution collected is about US\$7,750 per year that permits the employment of 8 persons.
\end{abstract}

This operation collected 22.4 tons of waste per month between 2002 and 2007, waste that would have been otherwise thrown into the streams, directly improving the environment and the population's health in these quarters.

Keywords: Pre collection, domestic waste, participation, funding, Yaoundé.

\section{INTRODUCTION}

In the cities of the developing countries, the management of domestic waste absorbs from 40 to $50 \%$ of the councils budget $[1,2]$. The cities are often deprived of financial and human means, often receive subsidies from the State for recruiting national or multinational private companies which can assume the management and the exploitation of this field [3]. In this context, the efforts are related to collection of waste and their evacuation out of the urbanized part of the city. Very few studies are carried out in view of eliminating without any danger waste and in this context the ventilations, are only "dump" allowing the transfer of pollution from the urban centre towards the rural surroundings [2].

The period between 1991 and 1998 was considered as a period of hesitation in Yaoundé marked by the end of the State's subsidy of the service of waste collection [4]. The

*Address correspondence to this author at the B.P. 8390 Ecole Nationale Supérieure Polytechnique de Yaoundé, Cameroon; Tel: (237) 222245 47; Fax: (237) 222245 47; E-mail: emma_ngnikam@yahoo.fr private company at that time which was ensuring the collection and evacuation of waste in the town put an end to its service, allowing a global critical situation. In 1998, the waste collecting service was launched thanks again to a financial subsidy from the State and the financial contribution of the Yaoundé city council. In this context, a pre - collection of domestic waste in five slum districts pilot operation was initiated by the NGO ERA-Cameroun and carry out on the field by two small private operators (Tam Tam Mobile and GIC JEVOLEC). The participation of the council and the Yaoundé city council in this operation was not much considerable. The private company ensuring the removal of waste in the city, although it recognizes that the pre - collection had allowed it to increase the quantities collected, that is, their sales turnover, supports the operation at it strict minimum, by allowing the access to their bin by the pre - collection operators in order to dump there, waste collected from households. The system, even though it is recognized useful by the council authorities survives only thanks to the voluntary participation of the selected quarters households, thus the difficulty of the self management of the operation. 


\section{METHODOLOGY OF THE PILOT PHASE IMPLEMENTATION}

\subsection{The Action Preparatory Phase}

The methodology adopted to achieve the goals of this project during the preparatory phase which had lasted only a year included four different but complementary steps:

Coordinating meetings between the local partners: the local partners of this project are much diversified, thus the need to organize activities so that each one can fully play its role. A steering committee bringing together : researchers support NGO, the Yaoundé 6 council, "HYSACAM" and the Yaoundé city council each three months. Sensitizing and information meetings for the inhabitants each month have been organized six month before the beginning of the intervention. The population individual headcount and activities have been carried out in order to have a credible data base for the calculation of the level of waste concerned and possible awaited contribution from the population compared to waste, etc.

The population individual headcount and activities of the pilot quarters: An individual headcount of the population belonging to the pilot quarters was necessary to have a reliable data base on the potential number of people interested to the project, the future customers of the precollection service who shall be proposed. This activity concerned 2961 households in six quarters.

Investigations and interviews have allowed identifying the pre collection operators, interviews have been done with the key local stakeholders (quarter heads, associations, SME of the sector, etc.) on the role to be played in the operational phase of the project. In addition, documentary researches have been carried out for identifying similar experiences in other countries. This step ended up with the identification of the physical constraints of implementation of the pre collection operation in quarters (accessibility, density of houses, relief, etc). A study related to the agreement to pay, costs opportunities, behavior of the population towards waste, etc.

Participative identification of the pre-collection itinerary with the recipient population, cartography of the channel and the main dumping areas defined in conjunction with the municipal authorities and the service provider company in charge of collecting waste in Yaoundé.

\subsection{Before the Beginning of the Action on the Field}

At this level, the activities include:

Drafting of an analytical classification, in view of choosing small operators ${ }^{1}$ who shall be implied in the project. From the synthesis of discussions with various operators, ten criteria ${ }^{2}$ have been defined in order to choose the most relevant actors who shall be put into contribution in the realization framework of this project [5]. The application of these criteria to our data base of the 21 interviewed associations made it possible to preselect five actors ready to

\footnotetext{
${ }^{1}$ Some of this small operators are local association without experience with the waste pre-collection activity. Some are small enterprises.

${ }^{2}$ See the D05 action report; Programme "Sustainaible waste management and town sanitation" Diffusion Programme Solidarité Eau(www.pseau.org) and Partnership for Town Development ( www.pdm-net.org).
}

take part in the operational phase of the project. After analysis, two operators have been choosing to intervene in the project: they included GIC JEVOLEC for the two peripheral quarters and Tam Tam Mobile for the three main quarters in Melen.

Staff training of the operator and the provision of work materials to the selected operator. The taking into account of the wages of the personnel and operating expenses during the first 3 months;

Drafting of service specifications in conjunction with the population, the council and the Yaoundé city council. The definition of the price of the service compatible with the incomes of the inhabitants and the level of service awaited on the basis of results of the study of the agreement to pay.

\subsection{During the Operational Phase}

\subsubsection{The Creation of a Steering Committee Defining the Missions of the Various Actors}

A steering committee has been created. This committee has to define the mission of the various actors involved in the project: Yaounde City Council, Yaounde VI sub divisional council, ERA-Cameroun, the local operators, the private company (HYSACAM) and the population representatives. Residents are represented in the stirring community by the chief of the different quarters cover by the pre-collection activity and the representative of key association. They have to make pre-collection service available to all the population of their quarter and sensitize people to pay for the service.

\subsubsection{Integration and Participation of the Recipient Population}

At the end of the various meetings organized in the pilot quarters, the following basic principles have guided the action on the field: the household commitment to entrust its waste to the pre collection service provider is compulsory please explain, the committed household will pay the service provider in exchange to the pre collection service. The household who refuses to entrust his waste to the service provider is held to remove them itself and not to put it in rivers, gutters and in landfills.

To ensure itself of the functionality of these basic rules, the population at each level of the quarter has set up its local relay structure of five members whose role has consisted to: make sure that the recipient household pays the agreed contribution to the service provider, to make sure that the service provider regularly removes waste, settle possible disputes existing between the service provider and his customers, propose sanctions the households who dump waste at unauthorized areas by the Yaoundé 6 sub divisional council hygiene service. The quarter head in advance is considered as guest member of this committee where the entire population existing in the quarter shall be represented (women representative associations, youth, heads of blocks, notables and economic operators).

\section{RESULTS OBTAINED AND DISCUSSION.}

We will distinguish the results obtained during the operational phase $\mathrm{s}^{3}$, one year after the end of subsidies and five years after the end of subsidies.

${ }^{3}$ During the support period by the French Ministry of Foreign Affairs 


\subsection{Results of the Operational Phase}

\subsubsection{A True Partnership Between the Pre-Collection Operators and the Collection Company}

The various organized meetings have enhanced to achieve certain goals especially [6]:

- Hysacam is the only private company dealing with the collection of solid waste in Yaoundé. The relations between this company and small operators dealing also with solid waste were not smoothly functioning. They were full of prejudices and incomprehension before the project. This relation improved considerably thanks to the project, in such a way that the staff of the company is ready to continue with this partnership because it presently realizes that the two actions are complementary.

A "gentleman agreement" currently existing between this company and the service provider in charge of the pre collection, in such a way that the company avoids ensuring the door to door collection of the pre

\subsubsection{A Considerable Financial Participation of the Population}

In whole, the number of households ready to pay for the pre collection service has considerably increased before and after the pre collection action on the field. The most significant increase is observed in Melen IV where we went from $51 \%$ before the intervention to $87 \%$ one month after the effective launching of the project. In Melen III the increase is only $18,6 \%$ in the sense that we passed from $55 \%$ of intention to pay to $73,5 \%$ one month after the launching of the project. The increase in Mbenda still remains very low because we went from $59,6 \%$ of intention to pay to 61 , and $5 \%$ after the launching of the operation (Fig. 1). But with time, we notice that this households' keen interest is precarious and will not last.

We notice a reduction of the amount of the agreement to pay (ATP) for the pre-collection waste service. The greatest variation is observed in Melen III where we pass from an average of 1280 FCFA per month before the intervention to 600 FCFA per month afterwards (Fig. 2). This phenomenon

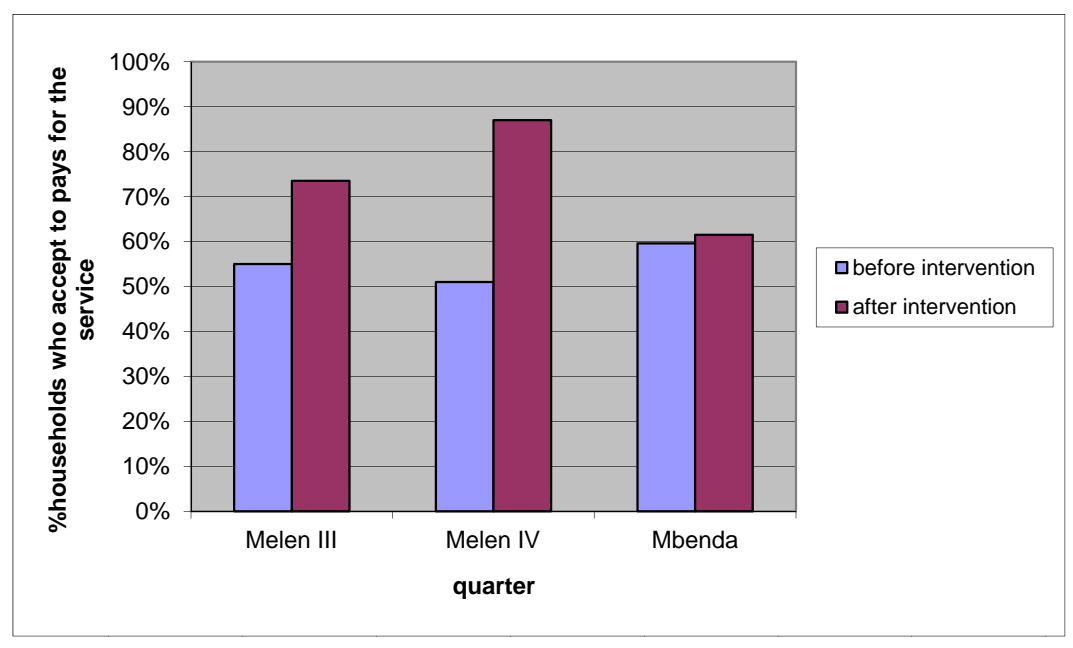

Fig. (1). Evolution of the agreement to pay of the households before and after the launching of the pre-collection activities on the field.

collection operators' action areas. It puts its vats at the disposal of the service providers for storing waste it transports to the landfill.

- $\quad$ The volume of waste collected by the local operators (Tam Tam Mobil and GIC JEVOLEC) has increased to $30 \%$ at Melen 3 and 4 and to $100 \%$ in Mbenda.

- $\quad$ At the end of the operational phase ${ }^{4}$ a direct relation exists between HYSACAM and the service providers. The latter directly inform HYSACAM of the problems within its competence.

The official acknowledgement of the work by the municipal authorities. The sub divisional council mayors and the government delegate have acknowledged the pre collection operation, the people who carry out the works on the field and are ready to collaborate in searching for solutions for the durability and the replication of this operation in other quarters in Yaoundé.

${ }^{4}$ Period of support by the Ministry for Foreign Affairs covering the 2000 to 2002 period. can be explained by the fact that the amounts proposed before the intervention did not really reflect what the household can pay. In fact, before the intervention, the majority of the households did not believe in the effectiveness of the operation and some proposed amounts just to please the investigators. After the operation, all the households become conscious that the service will be paying and the tendency is to propose low amounts so that the service should not be expensive to them.

Even if more than $80 \%$ of the surveyed households are willing to financially take part for the survival of the project, there exists a part of the surveyed households who manifest their reticence.

The pre-collection channel has been organized in the quarter and was charted in conjunction with the participation of the inhabitants. The intervention perimeter in Melen envisages six collection sectors employing 13 young people who serve 995 households just for the Melen sector, having a global population of 6000 inhabitants. The work schedules are fixed in conjunction with the population and an invoicing 


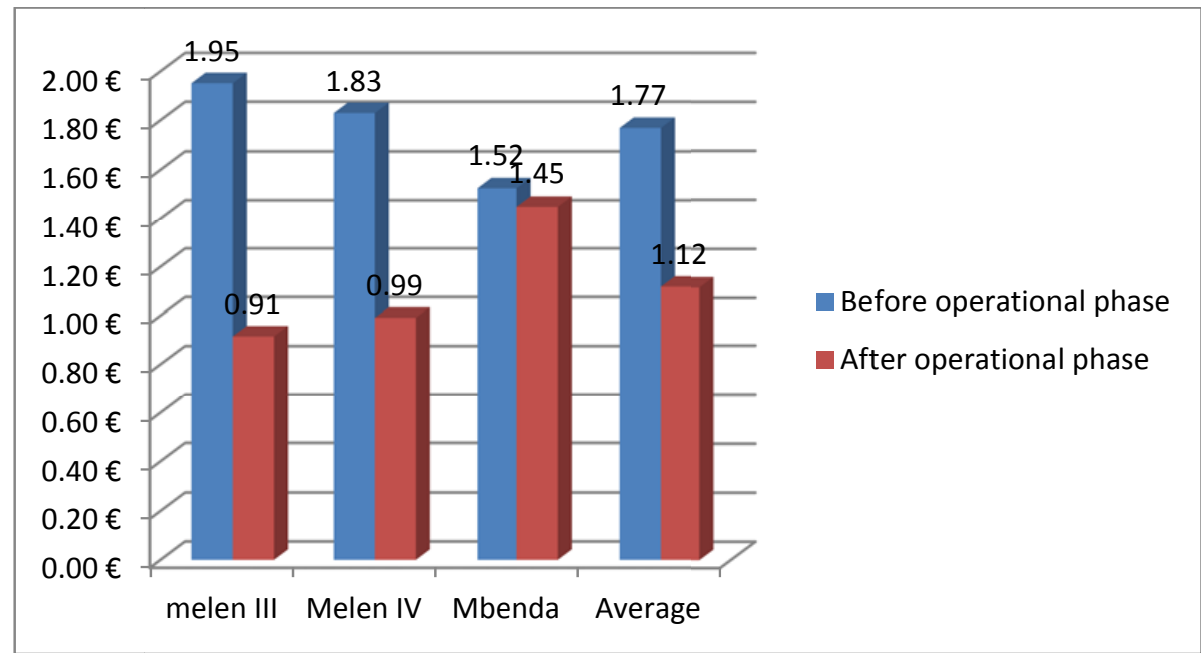

Fig. (2). Proposal of the monthly amount to pay by the households before and after the implementation of the action in different quarters involves.

service is set up by the pre-collection operator. Three rates of payment are proposed according to the results of the study of the agreement to pay and after consultation of the various populations present the project area:

- $\quad$ A special rate for students living alone fixed at 100 FCFA per month;

- $\quad$ A rate of 500 FCFA per month for households of not more than 3 people;

- A rate of 1000 FCFA per month for households of more than 3 people.

\subsection{Assessment of the Operation One Year After}

\subsubsection{Socio- Economic Assessment}

On the socio-economic level, several results are still capitalized:

Tools for the action: A detailed pre-collection feasibility study has led to the creation of several essential tools for the analysis of the implementation of this type of operation in other cities of Cameroun: a choice of the operators based on the important criteria which have demonstrated their reliability in time, an assessment of the agreement to pay by the population which has been consolidated on the field and allows the definition of rate approved by all, specifications intervention of the service provider approved by the users on the one hand, the local authorities and private operator in charge of collecting waste, an analysis of similar experience feedback in other world underdeveloped countries allowing to anticipate possible blockings [7];

Dialogue between the actors reducing with time: The experience done here has showed that to avoid inhibitions and incomprehension between actors, spaces for fruitful dialogue, mediation and negotiation are necessary in order to settle disputes and to promote harmony between different components of the population. This is possible only if each actor plays his role and brings a support to the committed operation [1]. With time, we have observed the reduction of commitment by the local authorities on the one hand who do not fully mobilize themselves for the promotion of this type of project because of budgetary constraints. In fact, according to the statement from the Yaoundé city council, if the pre-collection is organized in all the slum district of the city, that would involve an increase from 20 to $30 \%$ of the quantity of waste to be collected and transported to the landfill. The council budget cannot support such an increase. The private collection operator present in the city sees in this type of operation a competition which does not pronounce itself. According to him, if the pre-collection must be organized in the city, it would be necessary to integrate it in the specifications so that it continues to perpetuate the monopoly situation.

Complementarity between pre collection and collection: Pre-collection (i.e., collectors taking waste from households to public places) makes it possible to get in inaccessible areas by garbage trucks so as to bring it till the collecting areas. In Melen, the operation has made it possible to remove from the quarters, 3 tons of waste per day, which would be thrown in gutters, rivers and caused various harmful effects. Hysacam has acknowledged an increase of $30 \%$ of waste collected in Melen.

A passion of the served households in spite of the reduction of customer: The number of served households passed from 995 at the launching of the operation (free phase) to 400 from the first month of the contribution and 300 at the end of the first year [7]. This reduction was not entirely translated on the quantity of waste removed because of the households which under rent their subscription to the neighbors. This operation allows removing 3 tons of waste per day and employs 13 persons at the end of the first year. Despite everything, $95 \%$ of the households belonging to this area are satisfied with the operation at the end of the first year.

\subsubsection{On the Financial Level}

The pre-collection financial viability is blocked because of the households low payment capacities. The financing based on a direct fee from the users is insufficient to cover the operating costs. The annual balance sheet of the operating statement of the waste pre-collection operation at Melen in Yaoundé is negative. This situation had already been envisaged by the results of the feasibility study. The 


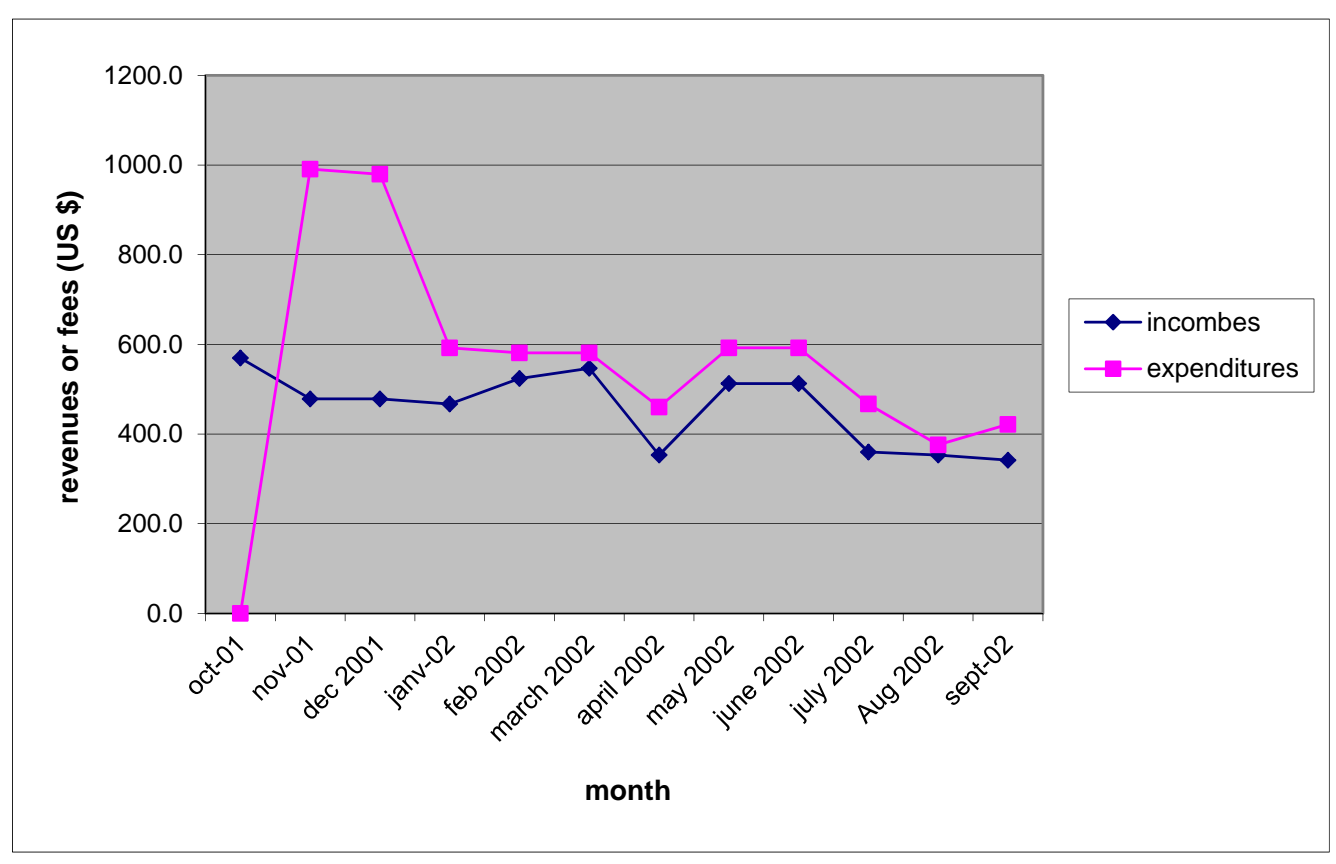

Fig. (3). Balance sheet of the pre-collection operation during the first year.

global deficit combined at the time of the first year of the action was 408140 FCFA $(622,20 €)$. This deficit was filled in during the period thanks to the external subsidies. An external support to the financial effort of the users is essential to last this type of operation. However, we have noted that the number of customer during the year varies according to the period of the school holidays; this has a significant influence on the incomes (Fig. 3) [7]. This project can not by financially viable with only the financial participation of the local population.

In order to last the action with time, the operator has been obliged to adjust the manpower and reduce the training rate. This adjustment has a limited impact on the quality of service for the customers, on the other hand the renewal of the garbage collectors small protection equipments, and the pre-collection materials could not be assured any more.

\subsection{Assessment of the Operation 5 Years After}

\subsubsection{On the Economic Socio-Level}

This action demonstrates that pre-collection, as a "traditional" activity bringing together working force, has its place in the channel of waste management in a large city and that it can allow, in long term and on a basis of new financing mechanisms, to considerably increase the covering rate of the service of waste collection. We note that the state of hygiene in the quarters which have benefited from this operation is considerably improved compared to the other quarters located in the basin. In spite of the financial problems, we strongly believe that this project is an initiative to be generalized and to last it in the basin. In fact, among the conditions having contributed to reduce the participation of the inhabitants in the project, we have listed internal and external factors in the quarters. Among the external internal factors in the quarter, we quote:

The limit covered by the project: The are not physical limit between two quarters of the basin, the fact that the inhabitants located apart from the zone of project continue to throw their waste in the drains, reduced the efforts of those who take part in the operation. This problem of limit is very clearly observed along the drains located at the limit of the covered quarters and the Mingoa River which are the natural limit between Melen III and IV quarters and Elig Effa quarter located on the other catchment. The taking into account of the catchment area, as territorial limit of such an operation can contribute to reduce the differences between quarters and to encourage the whole of the inhabitants to take part in the project.

Lack of institutional support at the local level and the council: If the role of the city council and the Yaoundé VI sub divisional council has been clearly defined and agreed in the beginning of the operation, it was noted that these institutions do not show any keen interest to support this type of operation. Thus the laxity behavior leading the operation to function by its own means and even dies if necessary. This lack of keen interest from the municipal authorities brings out the problem of equity in the access to the public services. Households considered as rich located in not poor quarters near tarred roads in the basin, their waste is removed without any financial constrain, meanwhile, the poor households located in the half-slope and hollows, do not profit from any assistance, even if they are ready to pay fees for collecting their waste till the large dustbin located on the tarred roads accessible by trucks. The support needed from the council is far to a financial one. It was expected that the council plays a key role in hygiene supervision by convincing the households refusing to adhere to the project to go and throw their refuse in the vats. According to the president of the association Tam Tam mobile, "the inhabitant does not know to whom he shall address his complain in case of misbehavior from his neighbor. We receive complaints and we limit ourselves to sensitizing ". The chief and the local association of the quarter do not want to be also involved in sensitizing the inhabitants; they prefer keep quiet in case of a 
misbehavior from the inhabitants because of the neighbors' sensitiveness. Each person prefers not to have a useless conflict with his neighbors because of dirtiness.

\subsubsection{Financial Assessment}

On the financial level, the pre-collection operation balance remained precarious for all the period. With the withdrawal of the donor, only the recipient population continued to pay for the functioning of the service in their quarter. The positive result of the improvement of hygiene and sanity conditions in the demonstration area constitutes the only motivation factor for the inhabitants. This dynamism strongly relied on the will and commitment of the members of the Tam Tam Mobile association leading the operation on the field. To adapt to the precariousness of the financial incomes, the association has reduced its staff from 13 to 7. The supervisor working in part-time and in a voluntary way. Instant assistance from ERA-Cameroun as far as small equipment (boots) is concerned allows when they come to raise the treasury of the operation. Fees for the renewing the work materials is too expensive (for instance 107000 FCFA of cash deficit in October 2004 (Fig. 4), following the renewal of work uniforms, transportation bags and other small equipment).

According to the Tam Tam Mobile president, "the association supports the addition fees while deducting from the profits realized in its connate activities, by solidarity to the members who work in the project and especially also thanks to the concern of the population who has yet acquired good reflexes and favorable behaviors". On the whole of the period from September 2004 to August 2005, the precollection operation has cumulated a deficit of 192280 FCFA, the most overdrawn month being October 2004. This deficit is due to the purchase of the garbage collectors uniforms and renewal of bags useful for storing waste before transportation. January 2005 and December 2004, thanks to the support in small equipment brought by the Environment and Science of Water Laboratory (purchase of boots and small work equipment) has had a meagre improvement in the project treasury.

\subsubsection{Environmental and Medical Assessment}

On the environmental level, this operation makes it possible to remove 22,4 tons of waste from households to public sites each month which would have been dumped in gutters or burnt in open air. It also contributes to improve health and well being of the inhabitants living in the project area. This operation has created an opportunity for dialogue between local authorities, private company, researchers and small waste pre collection operators. In 2008, that is 7 years after the implementation of the operation, the opinions of the populations of the recipient quarters are still positive on the level of improvement of health and environment of their quarter (Fig. 5) [8].

In the project area, the population is unanimous on the positive impacts of the project. In fact, the project has permitted to reduce: floods, mice and cockroaches in the houses, child labour ( 80 to $90 \%$ of favorable opinion), heaps of dirt in the quarters. In addition drains and rivers are very clean.

\section{CONCLUSION}

The success of the pre-collection-missing specification at the beginning of the paper in our cities of under developing countries is ultimately a matter of partnership between the emerging actors and the structures in charge of ensuring collection and transportation of waste in the city. If this partnership is not clearly understood by all, it will become difficult to achieve the goals pursued as far as town cleanliness is concerned. The participation of the users and the council in this partnership is indispensable for, it is necessary to create landfills, paying the service providers and ensuring the follow-up of the quality of the service. The precollection came to birth in an inexperience city and has found a request from households. In 2007, thanks to a support from UNDP, this operation was extended in 12 quarters in the catchment area. The follow-up of the activities of the project after the extension will in the end

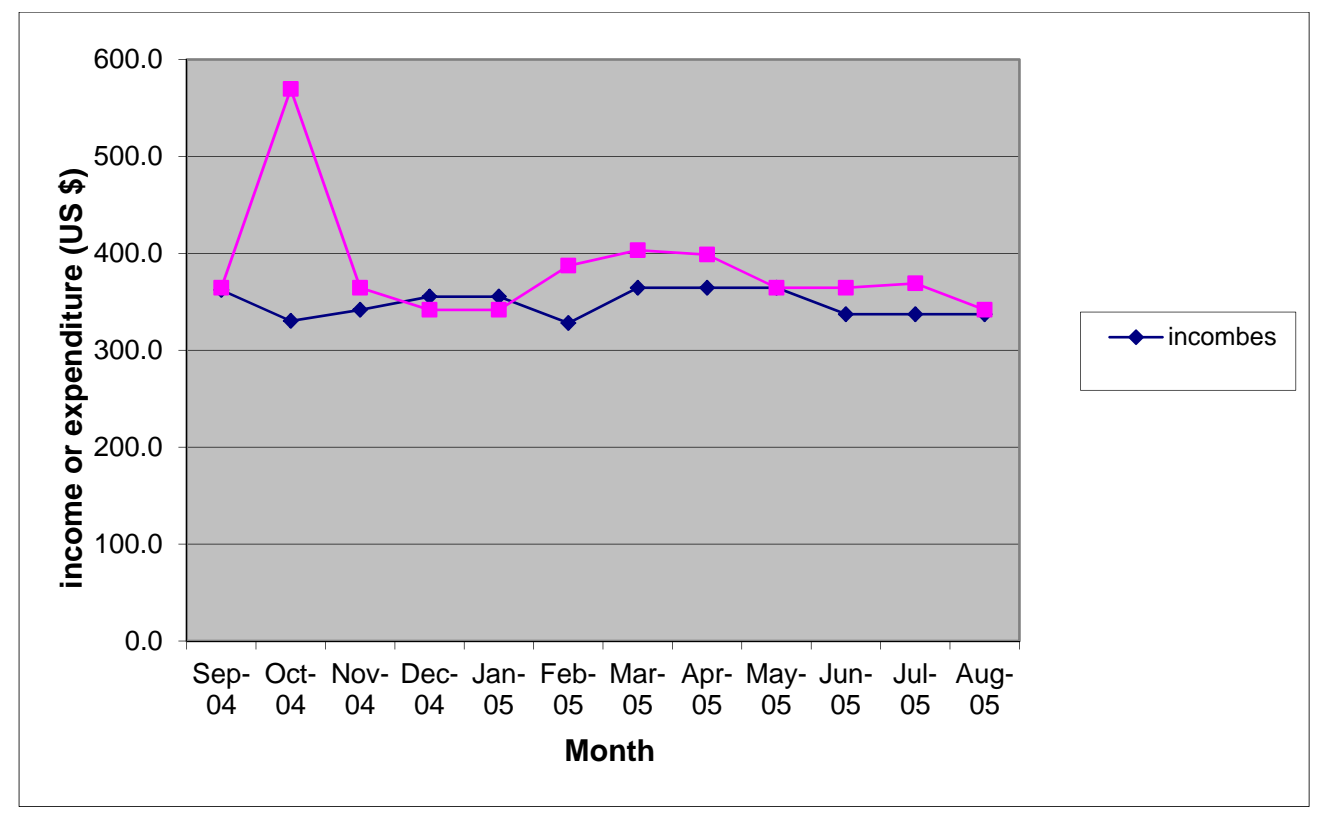

Fig. (4). Exploitation balance between 2004 and 2005 (5 after the beginning of the operation). 


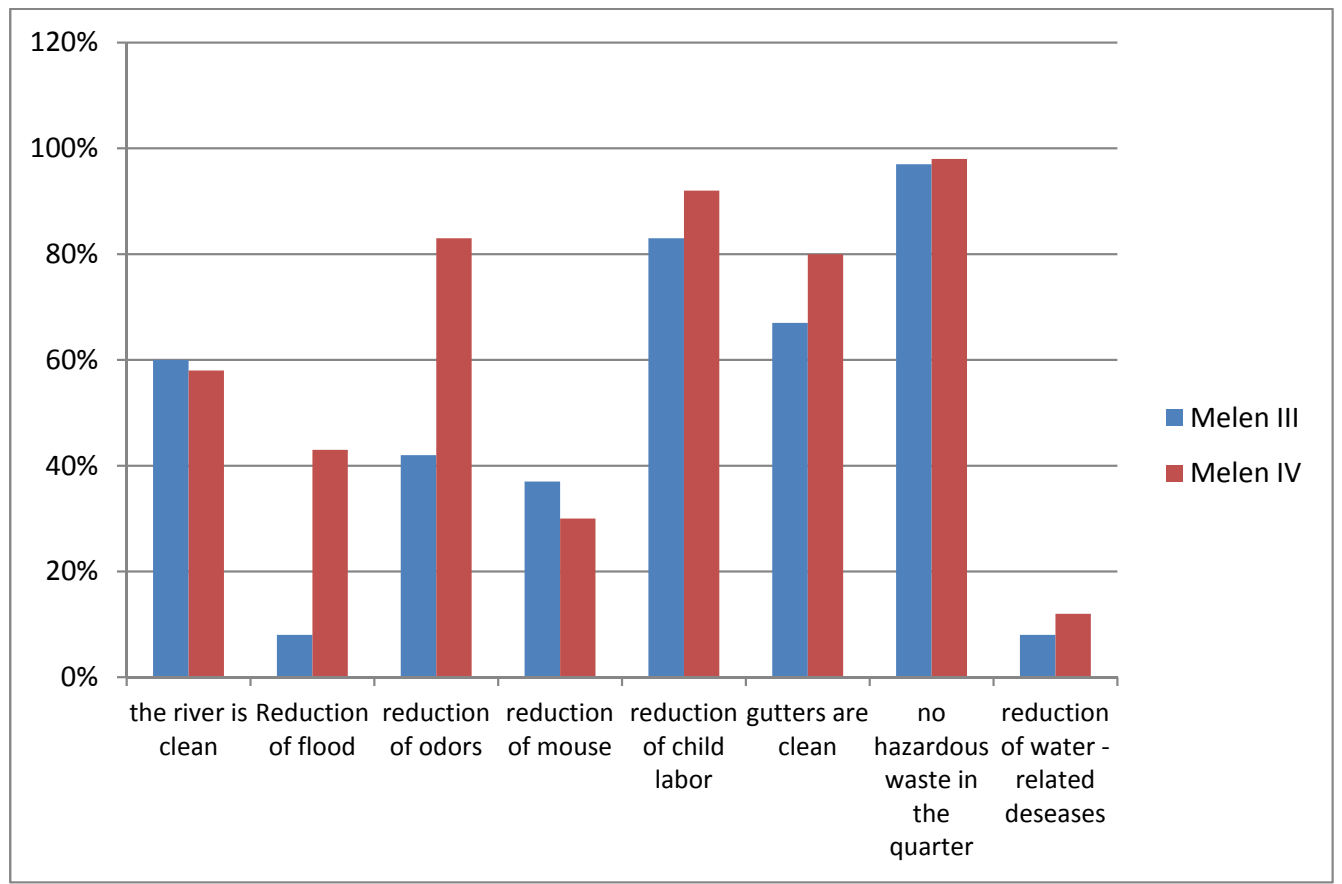

Fig. (5). Environmental and sanitation impacts of the project.

consolidate the results obtained in this action realized only in 2 quarters and define all the elements necessary to a changing of scale. The benefit on health in general and the populations well being is perceptible. The strong implication of the recipient population, coupled to an important mobilization of the pre-collection operator has permitted to the action to currently exist almost ten years without external contribution and in spite of the non important implication of the council authorities.

\section{ACKNOWLEDGEMENT}

Declared none.

\section{CONFLICT OF INTEREST}

The authors confirm that this article content has no conflict of interest.

\section{ABBREVIATIONS}

$\begin{array}{ll}\text { NGO } & \text { Non Gouvernemental Organisation } \\ \text { ERA-Cameroun }= & \begin{array}{l}\text { Environment Research and Action in } \\ \text { Cameroon }\end{array} \\ \text { GIC GEVOLEC }= & \begin{array}{l}\text { Groupe d'Initiative Commune (Small } \\ \text { Economic private group). }\end{array} \\ \text { UNDP } & \text { United Nation Development Program }\end{array}$

Tam Tam Mobile $=$ A local pre collection operator

HYSACAM = Hygiène et Salubrité du Cameroun (a pravite operator)
SME $=$ Small and Medium Enterprises

\section{REFERENCES}

[1] Anonyme, Programme "gestion durable des déchets et de l'assainissement urbain». Diffusion Programme Solidarité Eau (www.pseau.org) et Partenariat pour le Développement Municipal (www.pdm-net.org). Rapport de synthèse. 2004, p. 191.

[2] Emmanuel NGNIKAM et Emile TANAWA. Les villes d'Afrique face à leurs déchets. Edition de l'UTBM (Université de Technologie de Belfort-Montbéliard). Décembre 2006, p. 281.

[3] Mouafo Valentin, 2011. Déchets, développement durable et OMD. Revue Liaison Energie-Francophonie, $n^{\circ} 90,4^{\text {ème }}$ trimestre 2011, pp. 910, www.iepf.org

[4] NGNIKAM, E. Evaluation environnementale et économique de systèmes de gestion des déchets solides municipaux : Analyse du cas de Yaoundé au CAMEROUN. Thèse LAEPSI. Lyon : INSA de Lyon, mai 2000, p. 363.

[5] Zahrani Fouad, Pascale Naquin et E. Ngnikam, 2006. Pré-collecte des déchets ménagers dans les pays en développement: comment évaluer les actions menées? Revue francophone d'écologie industrielle, $\mathrm{n}^{\circ} 43$, septembre 2006, pp. 31-43.

[6] ERA-Cameroun, 2002. Mise en place de structure de pré-collecte et de traitement des déchets solides urbains dans une capitale tropicale : cas de Yaoundé au Cameroun. Rapport d'action pilote. Yaoundé, septembre 2002. p. 182.

[7] Tanawa E. et Ngnikam E., Programme « gestion durable des déchets et de l'assainissement urbain », comment aller plus loin dans le cas du Cameroun. Actes de Colloques. Yaoundé, février 2004, p. 123.

[8] YUMGBO Ouamba A, 2008. L. Gestion durable des ordures ménagères dans les quartiers spontanés de Yaoundé au Cameroun: optimisation du système de pré-collecte dans les quartiers Melen 3 et 4 . Mémoire de fin d'étude, Ecole Africaine des Métiers d'Architecture et de l'Urbanisme de Lomé. juillet 2008, p. 92. 